\title{
Appendix 1: An Overview of Delphic History
}

The Neolithic period

The Mycenaean period

Mid-seventh century все

Late seventh century BCE

Early sixth century BCE

sixth century BCE

$595^{-5} 85^{\text {B CE }}$

586 в Се

548 вСЕ

$449-448$ вСЕ

$373 / 2$ В СЕ

$356-346$ в Се

339- 338 ВСЕ

279 BCE

200-197 BCE

18 о В CE

168 вСЕ

$88-63$ ВСЕ

29 BCE

$84 \mathrm{CE}$

c. $165^{-180 ~ C E}$

c. $193-217$ CE

$38 \mathrm{OCE}$ the earliest attestations of the occupation of Delphi

attestations of settlement and cult

erection of the first stone temples of Apollo and Athena

erection of the Corinthian Treasury

construction of the first peribolos walls (final separation of the sacred space from the domestic space)

erection of other treasuries and the bouleuterion

the First Sacred War

inauguration of the Pythian Games ${ }^{1}$

destruction of the temple by fire and the rebuilding

action by the Alkmeonides

the Second Sacred War

destruction of the temple by earthquake

the Third Sacred War

the Fourth Sacred War

the Gaulish invasion and the beginning of 'the Aetolian period' at Delphi

the Second Macedonian War

the battle of Magnesia and the shedding of the Aetolian yoke

the battle of Pydna

the Mithridatic Wars and the cancellation of the

Pythian Games of 86 вС

the foundation of Nikopolis by Augustus and its inclusion in the Amphictyony

the reconstruction of the temple of Apollo by Domitian the Antonine plague

another renovation of the temple of Apollo

the edict of Theodosius that banned all religions except Christianity, closed all oracular shrines and forbade the organisation of the ancient games

1 The first stephanitic Pythian Games (i.e. for which a crown was the victory's prize) took place in $582 / 1$ вCE. See Weir 2016, 14.

(C) DOMINIKA GRZESIK, 2021 | DOI:10.1163/9789004502499_010

This is an open access chapter distributed under the terms of the CC BY-NC 4.o license.ka Grzesik - 9789004502499 